\title{
ЈЕДАН ПОГЛЕД НА НОВИЈУ СРПСКУ ПРИПОВЕТКУ
}

Два века српске уметничке приповетке, то је, уз поезију, најјаснији континуитет у датој националној књижевности, а у естетском смислу и њена највећа вредност. Песма и прича су основ сваке књижевности: ко то нема, нема откуда да крене, нити има чему да се врати. Традицијом je, дакле, установљено, а делом Иве Андрића практично потврђено да су прича, приповетка и приповедање основно, идентитетско питање српске књижевности. Извори, боље рећи, кључеви српске приповедачке уметности су, без икакве сумње, у њеној усменој традицији: та уметност у свом памћењу нема ни Сервантеса, ни Бокача, ни Чосера, али има усменог народног генија. Пошавши од својих фолклорних корена, па постепено, у XIX веку и почетком XX столећа усвајајући поетичке особине европске новелистике, и укрштајући их са домаћим специфичностима, прича и приповетка постале су кичмена нит целокупне српске књижевности.

Тако посматрана, историја српске приповетке заправо је историја смењивања различитих поетичких предложака и деловања надахнутих појединаца, са низом етапа које можемо одредити као обликовно, типски битне, а естетски репрезентативне. Прво „златно доба” српске приповетке је епоха реализма, са остварењима Лазе К. Лазаревића, Симе Матавуља и Стевана Сремца. Потом је уследила модерна, са Бором Станковићем као најзначајнијим приповедачем, те „лирским реалистима” Петром Кочићем, Светозаром Ћоровићем, Вељком Милићевићем и Милутином Ускоковићем, као и Вељком Петровићем, Исидором Секулић, Станиславом Винавером и другима тада новим прозаистима. Први модернизам, после Првог светског рата, донео је капитална приповедачка дела „модерних класика” 
Иве Андрића, Милоша Црњанског, Драгише Васића, Растка Петровића и Момчила Настасијевића, а други модернизам започео је приповеткама Владана Деснице и Миодрага Булатовића, да би у доцнијим деценијама доживео низ индивидуалних стваралачких промена, каткад са обновљеним реалистичким предзнаком (Антоније Исаковић, Драгослав Михаиловић, Момчило Миланков), каткад са ознакама високог модернизма (Александар Тишма, Борислав Пекић, Данило Киш, Милорад Павић), каткад на начин веризма и неонатурализма (Живојин Павловић, Видосав Стевановић, Милисав Савић, рани Мирослав Јосић Вишњић).

Почетком 80-их година XX века високи модернизам постепено добија обрисе постмодернистичких наративних стратегија (Давид Албахари, Светислав Басара, Радослав Петковић), да би се током 90-их, сагласно новим историјским трусним померањима, у делима новопристиглих приповедача поново променила наративна матрица. Уместо коментара текстуалног предлошка, што је својствено александријски расположеним постмодернистима (које делимично следе у међувремену афирмисани Горан Петровић, Владимир Тасић и Владан Матијевић), изнова је откривена и коментарисана непосредна, опипљива, морбидна стварност, у толикој мери, и са таквим интензитетом да би се могло рећи да је стварност присилила писце да промене тему, намећући им својеврсну „поетику проговора”. Крај минулог века и прве године новог столећа донели су извесно смиривање, па се са доста основа може закључити како у савременом стицају српских приповедних околности заправо и нема доминантног стила, већ је на делу међусобно, латентно, а понекад и отворено полемичко комешање често и сасвим опречних поетичких позиција, од којих свака за себе мисли да је највреднија и пресудно важна у актуелном књижевном контексту. Влада весела и махом плодотворна збрка најразличитијих могућих стваралачких концепција, оријентација и усамљеничких креативних чинова, с тим да се, осим природне борбе за престиж између различитих типова нарације, што постоји откада постоји и модерно приповедање, може приметити понекад врло снажна, понекад притајена, али и даље делатна, донекле и идеологемски обликована, криптополитички подстицана поларизација различитих приповедних погледа на свет.

У таквом распореду фигура на књижевној шаховској табли на једној страни стоје они писци и њима склони критичари који се тематски и по примењеном наративном типу декларишу као „традиционалисти”, док су на другој они склонији наглашавању веза са европским и светским књижевним контекстом, па је њима у жаргону књижевног живота намењена ознака „постмодерниста”, истина, данас са нешто мање негативне острашћености него током 90-их година. Златна средина је, по правилу, равнодушна. То, строго узев, није никаква посебност данашње српске приповедачке сцене (само се због екстремности непрестане друштвене кризе то изразитије 
види), већ је нужност у преображајима готово свих уметности у „прелазним” раздобљима, када видно опада некада тако изражена, идеолошки промовисана и подстицана социјална, друштвенокорективна функција уметности, а до изражаја долазе тржишни критеријуми.

Са успостављањем каквог-таквог тржишта књижевности радикално се мења и статус српске приповетке. Од некада доминантне и репрезентативне форме она, као и готово све друге књижевне врсте, изузев романа (и, делимично, драме), напросто постаје мање фаворизована и оглашавана, али, упркос томе, задржава квалитет и особине елитне књижевне врсте, са недвосмисленим уметничким угледом. Тако српску приповедну савременост обележава један очигледан парадокс: она, наиме, успева да добрим делом остане на обликовном и естетском нивоу који је установљен и задат традицијом, а у најбољим моментима да ту традицију и унапреди, помери и уздигне на још суптилнији ниво, но та померања ни издалека не прати интересовање публике и критике какво је постојало у не тако давној прошлости. Захваљујући једној престижној награди, са именом Иве Андрића, која је, када говоримо о оствареним вредностима, имала мање осцилација од најпрестижније награде за роман (Нинова награда), ипак је у области приповетке сачувана релативно целовита представа о темељним приповедним поступцима и вредносним проценама. Хронологији те награде посвећена је антологија Прича и причање (2001) коју је приредила Жанета Ђукић Перишић. Ауторитет Андрићевог дела очигледно и даље снажно утиче не толико на поетички лик српске приповетке, колико је мера вредности у њој. Тај ауторитет као да намеће приповедни стандард у међувремену допуњен низом значајних остварења писаца који су, сви листом осим Борислава Пекића, ту награду добили (Драгослав Михаиловић, Александар Тишма, Давид Албахари, Данило Киш, Видосав Стевановић, Радослав Петковић, Мирослав Јосић Вишњић и други).

Иако више не доминира и мада, као ни поезија, није медијски повлашћена (осим у тренутку доделе награда у славу великих приповедачких имена: „Бора Станковић”, „Стеван Сремац”, „Вељкова Голубица - Вељко Петровић"), а тржишно је готово потпуно неатрактивна и занемарена, па би се могло рећи да опстаје у кругу посвећеника, што самих писаца, што критичара, што ентузијастичне групе читалаца, данашња српска приповетка није, како би се споља могло очекивати, сведена на једну или две обликовне димензије, већ је задржала и додатно проширила своју обилност, тако да је у њој могуће стално разликовање мноштва поетичких и индивидуалностваралачких ликова, почев од оних приповедача који су баштинили и који и даље продужавају традицију ,доброг старог” реалистичког приповедања (Драгослав Михаиловић, Данило Николић, Младен Марков, Жарко Команин, Момо Капор, Жика Лазић, Данко Поповић, Петар Пајић, Милисав Савић, Јанко Вујиновић, Радослав Братић, Јован 
Радуловић, Милорад Грујић, Славко Лебедински, Тихомир Нешић, Саша Хаџи Танчић, Бранислав Станојевић, Божин Јаневски, Радосав Стојановић, Ђуро Дамјановић, Ранко Павловић, Ранко Рисојевић, Миленко Стојичић, Славен Радовановић, Душан Прелевић, Драги Бугарчић, Лабуд Драгић и други), као и они који су интензивније мењали своју поетику, каткад ближе наративном експерименту (Воја Чолановић, Павле Угринов, Бора Ћосић, Мирко Ковач, Драго Кекановић), каткад наглашено лирском и фантазмагоричном приповедном проседеу (Мирослав Караулац, Филип Давид, Јаков Гробаров, Светозар Влајковић, Марко Недић, Војислав В. Јовановић, Мирослав Јосић Вишњић, Јовица Аћин, Радован Бели Марковић). Некадашњи, барем на први поглед релативно конзистентан корпус аутора „стварносне прозе” у међувремену је раслојен, а исти је случај и са постмодернистички настројеном генерацијом писаца која их је сменила. Првом корпусу који је у смислу поетичке иницијације обележио раздобље од 1968. до 1980. године посвећена је антологија Нова српска приповетка (1972) Љубише Јеремића, а њој је донекле блиска и Српска приповетка 1950-1982 (1983) Радивоја Микића. Копрусу постмодернистичког приповедања посвећене су Антологија српске прозе постмодерног доба Александра Јеркова (1992) и антологија Нова (постмодерна) српска фантастика $(1994,2004)$ Саве Дамјанова. Уз писце - навеститеље појаве постмодерних наративних решења која укључују крајње ироничан, демаскирајући однос према историји и стварности, сталну цитатну игру, релативизацију приповедног говора, па и декомпозицију саме приче схваћене као опис или извештај о збивању са јасним карактерима, заплетом и просторновременским координатама, Јерков и Дамјанов представљају приче и приповетке Драгана Стојановића, Јовице Аћина, Давида Албахарија, Светислава Басаре, Радослава Петковића, Михајла Пантића, Миленка Пајића, Драгана Великића, Ђорђа Писарева, Предрага Марковића, Мирослава Тохоља, Саве Дамјанова, Милете Продановића, Владимира Пиштала, Немање Митровића, Сретена Угричића, Миодрага Вуковића, Велимира Ћургуса Казимира, Љиљане Јокић Каспар, Васе Павковића, Љубице Арсић, Горана Петровића и Дивне Вуксановић. У још ширем информативном прегледу њима треба додати и приповедачка остварења Бранка Андрића, Слободана Тишме, Владислава Бајца, Бранка Анђића, Славољуба Марковића, Милоша Латиновића, Теофила Панчића, Небојше Ћосића, Милена Алемпијевића, Марка Видојковића, Боривоја Адашевића и других. Већина побројаних писаца и даље је приповедачки врло активна, с тим што су се неки од њих у међувремену окренули и писању романа, а посебну пажњу треба обратити на низ песника који искуство писања поезије све чешће, са занимљивим резултатима, замењују писањем прича или романа (нешто раније Миодраг Павловић и Милорад Ђурић, потом Војислав Деспотов и Милош Комадина, а данас Васа Павковић, Рајко Лукач, Милован Марчетић, Иван Негришорац и други). 
Корпусу савременог женског приповедања, који крајем XX и у првим деценијама XXI века доживљава видан раст, као и одговарајућу реакцију књижевне критике, укључујући ону одређену методолошком позицијом родног тумачења текста, посвећена је антологија Рајка Лукача Антологија приповедака српских књижевница (2002) у којој су заступљене приповетке од Данице Марковић, Милице Јанковић и Исидоре Секулић закључно са Мирјаном Митровић, Мирјаном Новаковић и Јеленом Росић. Потом следи антологија Женски континент - антологија савремене српске женске приче (2004) коју је сачинила Љиљана Ђурђић, и сама приповедачица. Списатељицама заступљеним у тој антологији (Јудита Шалго, Мирјана Павловић, Елвира Рајковић, Милица Мићић Димовска, Боба Благојевић, Љубица Арсић, Снежана Букал, Нина Живанчевић, Марија Иванић, Јелена Ленголд, Даница Вукићевић, Марија Кнежевић, Дивна Вуксановић) у овом прегледу треба придодати и Светлану Велмар Јанковић, Виду Огњеновић, Биљану Јовановић (која је, иако превасходно романсијер, за живота у периодици објавила и неколико примећених прича), Иванку Косанић, Радмилу Гикић Петровић, Марицу Јосимичевић, Марину Костић, Јасмину Тешановић, Љиљану Јокић Каспар, Стану Динић Скочајић, Гордану Ћирјанић, Ивану Димић, Снежану Јаковљевић, Емсуру Хамзић, Мирјану Митровић, Емилију Миловановић, Светлану Поровић Михајловић, Соњу Атанасијевић, Лауру Барну, Сању Домазет, Биљану Т. Петровић, Слађану Илић... Коначно, ту је и Антологија женске приповетке од 1950. до 2017. године Славице Гароње - Врт наде (2017) - у којој су заступљене приповетке од Светлане Велмар Јанковић и Јаре Рибникар закључно са Весном Капор и Слађаном Илић.

Женска прича и приповетка данас представљају врло разуђено стваралачко подручје, унутар којег постоји низ изразитих индивидуалности важних не само за укупан утисак о изобиљу савременог српског приповедања, него и за илустрацију коренских поетичких промена, односно усвајања нових приповедних модела. Ако је у прошлости, нарочито у XIX, а претежним делом и у XX веку, прича била превасходно мушки посед, укључујући и њен базични, историјско-хроникални, ауторитарни модел овладавања истином света, махом из ,јаке” перспективе, са спорадичним женским искорацима (Исидора Секулић, Даница Марковић, Јелена Димитријевић, Милица Јанковић, Јулка Хлапец Ђорђевић, доцније и Јара Рибникар, Фрида Филиповић, Јулија Најман, Гроздана Олујић, Вера Колаковић и друге), приповедачице су током минулих тридесетак година показале и амбицију и неспорну вештину „овладавања” причом, што је донело и низ изврсних приповедних резултата.

Новији талас српских приповедача који су стасали у временима сумануте друштвене кризе и потпуно изобличене политичке и ратне стварности најпотпуније је, за сада, представљен у Антологији младих српских при- 
поведача - Тајно друштво (1997) Васе Павковића и Ослобађағу лектире - антологији српске кратке приче (2003) Игора Маројевића, у којима су, између осталих, заступљене приче и приповетке Срђана Ваљаревића, Нарциса Агатића, Зорана Ћирића, Вулета Журића, Веселина Марковића, Нине Рабреновић, Јелене Росић, Владимира Тасића, Ђорђа Јакова, Микаила Бодироге, Горана Петровића, Дејана Илића, Зорана Пешића Сигме, Александра Гаталице, Саше Обрадовића, Саше Илића, Мирјане Новаковић, Слободана Владушића, Срђана В. Тешина, Слободана Илића, Ненада Јовановића, Игора Маројевића и Михајла Спасојевића.

Осим издашне приповедачке и антологијске продукције којом се покривају, представљају и тумаче готово сви тематско-приповедни модалитети савремености и традиције (када је о традицији реч, посебно треба видети Антологију српских приповедача 19. и 20. века, 1999, Мирослава Јосића Вишњића; Приповијетке српских писача из Хрватске - антологија, 2004, Душана Иванића и Антологију српске приповетке 1-3 Михајла Пантића, 2005), необична, па донекле и ексцентрична посебност актуелног српског приповедачког тренутка су и нарочите књиге-пројекти у којима се, обично техником пастиша, али и тематско-асоцијативним проширивањем одабраног стилског или ауторског предлошка, одаје почаст утицајним, иконичним писцима из копруса светске књижевности (такви су Пројекат Сингер, 2001, Пројекат Кортасар, 2002, Пројекат Буковски, 2004. и тако даље) или се пак у иронично-сатиричном кључу преиспитују задати, окамењени, естетски непродуктивни наративни модели, односно, обрађују необичне, неконвенционалне теме (на пример: антологија Бизарних прича приређивачице Тање Росић, 2002, зборник приповедних реминисценција Мој приватни Тито, 2003, као и травестија наративних образаца „стварносне прозе" у колекцији Нема толико до Лајковия, 2004).

У закључку овог прегледа могло би се, са много разлога, и са стварним покрићем у готово недогледном мору савремених српских приповедака и приповедача, устврдити како не постоји ниједно поље овладаног искуства (дакако, фикционализованог и домаштаног) које није тематизовано у савременом српском приповедању, напосе у приповеци и у причи. Ослањајући се на богату и обавезујућу традицију, успостављену током XIX и XX века, савремени српски приповедачи настављају да граде велику имагинарну грађевину у којој се складишти све стварно и све могуће знање о човеку и свету, односно о човеку у свету. Чини се да је кључни квалитет савремене српске приповетке у томе што је, у већини најзначајнијих примера и случајева, како сам већ написао, „успела да се растерети од наметнутих прагматичних захтева и функционализација различитих врста, што је пречесто био случај у прошлости, и да остане оно што суштински јесте: уметност маштања и сведочења, разумевања и смисаоног проширивања живота, ма шта би реч живот у датом случају имала да значи". Српски 
приповедачи, оптимално користећи креативне потенцијале свога језика и духа своје и европске традиције и културе, а сагласно свом немалом дару, инвенцији и имагинативној снази, као и њихови давни и непосредни преци, смишљали су и смишљају, писали су и пишу приче које ће, сигурно, читати и неки будући читаоци. Тај имагинарни универзум њиховог приповедања уравнотеженији је, хармоничнији, па у том смислу и срећнији од света историјске и политичке стварности.

И сасвим на крају: припадајући типу културе која је, пре и после свега, култура приче (у екстрему - и култура епске распричаности, култура тежње да све заврши у причи), српски приповедачи кад-тад „опричају” све што је вредно приче и приповедања. Нужност је то првог реда, и њен је корен, сетимо се опет Иве Андрића, антрополошки. Прича уобличава наше знање о свету. Измишљањем прича, фикционализацијом искуства, превазилазимо ограниченост свакидашњице, искупљујемо и њу и себе, приближавамо се суштини без обзира на то што нам она и у приповедању стално измиче.

Да, приповедати је синоним за живети. 